Int. J. Dev. Biol. 55: 377-382

doi: $10.1387 / \mathrm{ijdb} .103215 \mathrm{ac}$

\title{
A brief history of angiogenesis assays
}

\author{
ANCA-MARIA CIMPEAN ${ }^{*}, 1$, DOMENICO RIBATTI ${ }^{2}$ and MARIUS RAICA ${ }^{1}$ \\ ${ }^{1}$ Department of Histology, "Victor Babes" University of Medicine and Pharmacy, Timisoara, Romania and \\ ${ }^{2}$ Department of Human Anatomy and Histology, University of Bari Medical School, Italy
}

\begin{abstract}
The major problem with angiogenesis research is the choice of an appropriate assay. Currently, many in vitro and in vivo techniques are available for research into the functions of endothelial cells during angiogenesis. In this historical review article, we describe and evaluate the methodology and specific features of some of the most frequently used of these assays.
\end{abstract}

KEYWORDS: angiogenesis assay, endothelial cell, in vtro model, in vivo model

\section{Pre-microscopic era}

The earliest descriptive references to the circulatory system are found in Edwin Smith Papyrus (17th century BC), containing the first description of heartbeat, followed by Ebers Papyrus (16th century BC), an ancient egyptian medical papyrus, which describes the connection of the heart to the arteries and reports the high vascularization of tumors (Willerson and Teaff, 1996). Alcmaeon of Croton (approximately $500 \mathrm{BC}$ ) an early pioneer of animal dissection, observed arteries and veins to be distinctive structures (Khan et al., 2005). Hippocrates (460-370 BC) noticed that blood vessels around a malignant tumor looked like the claws of a crab. He named the disease karkinos (the Greek name for crab).

Aristotle suggested that the heart along with blood vessels was the first structure to appear during embryogenesis (Crivellato and Ribatti, 2006). Herophilus of Chalcedon (300 BC) elaborated a distinction between arteries and veins and discovered that arteries contained blood rather than air (Fancher et al., 2008). This latter evidence was confirmed by Galen (Katz, 1957).

Ibn al Nafis, an eminent physician of $13^{\text {th }}$ century, discovered the pulmonary circulation and suggested that the coronary arteries function as suppliers of blood to the cardiac musculature (AlGhazal, 2007).

In 1569, Andrea Cesalpino (1519-1603) was the first one to coin the word "circulation" (Prioreschi, 2004), while the first scientist to use the word "capillary" was Leonardo da Vinci. Leonardo injected the blood vessels with wax for preservation, a technique still used today, and discovered and named the capillaries, although he did not understand the role they played connecting the arterioles and venules.

In a treatise published in 1628, Exercitatio anatomica de motu cordis et sanguinis, William Harvey (Fig. 1) described the two parts of the circulatory system and suggested the presence of the capillary bed, but he could not prove this theory (Ribatti, 2009).

\section{Microscopic era}

Jean Riolan (1580-1657) injected for the first time color dyes to demonstrate the branching of the vascular tree (Paweletz, 2001). Marcello Malpighi described capillaries in the renal glomeruli, in the mesentery and in the lung and studied the vasculature of the chick embryo chorioallantoic membrane in his work De ovo incubato published in 1671. He extensively performed vascular injection using ink, urine colored with ink, and black-colored liquid mixed with wine. Frederik Ruysch (1638-1731) used wax to inject the vascular system and proved the presence of the capillary bed in all tissues including vasa vasorum and bronchial capillaries (Hwa and Aird, 2007).

Diaphanization was also used for studying the vascular system rendering cadaveric tissues transparent by a series of chemical reactions accordingly to a method developed by Spalteholz (Spalteholz and Hirsch, 1907).

The first description of the endothelium was attributed to Theodor Schwann (Fig. 2) (Schwann and Schleiden, 1847). These data were obtained by injection of silver nitrate into the vessels followed by light exposure (Woodward, 1870), which allowed the definitive establishment of the presence of a cellular lining and hence the existence of a capillary wall. In 1862, von Recklinghausen stained the lymphatics with this method and was the first to observe that they were lined with cells (Warkany, 1981). In 1865, in his work titled Die Häute und Höhlen des Körpers (The membranes and cavities of the body), the swiss anatomist Wilhelm His used for

Abbreviations used in this paper: CAM, choriallontoic membrane; FGF, fibroblast growth factor. *Address correspondence to: Anca Maria Cimpean. "Victor Babes" University of Medicine and Pharmacy, Department of Histology and Cytology, Pta Eftimie
Murgu, 2, 300041 Timisoara, Romania. e-mail: ancacimpean1972@yahoo.com

Final, author-corrected PDF published online: 27 July 2011.

ISSN: Online 1696-3547, Print 0214-6282

(C) 2011 UBC Press

Printed in Spain 
the first time the term endothelium to define the inner layer of the blood vessels (His, 1865; Loukas et al., 2008).

As concerns the pericytes, in 1873, Rouget described perivascular cells with contractile properties with irregular cell bodies and the branched processes of which encircled the capillaries. In 1886, Zimmerman in 1886 using silver nitrate and in 1902, Mayer using methylene blue were able tostain these cells (Movat and Fernando, 1964). Moreover, Zimmerman introduced the term "pericyte" to define Rouget cells and postulated that contraction of these cells controls capillary permeability (Allt and Lawrenson, 2001). The theory that perciytes are active contractile elements was criticized by Sandison, Clark and Clark, and Zweifach (Sanders et al., 1940; Zweifach and Kossman, 1937).

Goldman (Goldman, 1907) and Lewis (Lewis, 1936) described many differences in the morphology of blood vessels among various tumors in rats and humans. Using a window model elaborated by Sandison (Sandison, 1927), Ide et al.,(1939) observed a potent angiogenic response after implanting a tumor in a rabbit's ear. Clark used the same experimental model to study the development and function of blood and lymphatic vessels (Clark et al., 1931; Clark, 1936, Clark and Clark, 1939).

In 1964, Weibel and Palade (Fig. 3) described for the first time the so-called "Weibel Palade bodies" in the cytoplasm of endothelial cells (Weibel and Palade, 1964). Today it is well known that a component of these bodies is von Willebrand factor and the FVIIIrelated antigen antibody is commonly used for the immunostaining of endothelial cells.

\section{In vitro models to study angiogenesis}

A critical issue in setting up an in vitro assay is the choice of endothelial cells. Endothelial cells derived form humbilical veins were first successfully cultured in vitro in 1973 by Eric $A$. Jaffe and co-workers (Jaffe et al., 1973). The first long-term passage of cloned capillary endothelial cells came later (Haudenschild, et al., 1975).

Ingber gave an important contribution in this field by demonstra- tion that cultured endothelial cells changes in cell shape can signal through integrins to regulate gene expression and DNA synthesis. He went on to develop an entirely new field of investigation of cell biology based on the mechanisms by which mechanical forces modify DNA synthesis and gene expression of emdothelial cells (Ingber et al., 1987).

Angiogenesis was first observed in vitroby Folkman and Haudenschild (1980). After long-term culture of capillary endothelial cells, these authors observed the spontaneous organization of these cells into capillary-like structures. Montesano contributed to clarifying some cellular and molecular mechanisms of angiogenesis using an original three-dimensional cell culture system which replicates key events of angiogenesis, thereby facilitating molecular analysis (Ribatti, 2010).

In vitro models of angiogenesis have focused on migration, proliferation amd tubule formation by endothelial cells in response to exogenous stimulatory or inhibitory agents. An important consideration when using endothelial cells stabilized in vitro is that they lose their phenotypic, antigenic and functional characteristics. Moreover, as angiogenesis commonly involves the microvasculature rather than the macrovasculature, an inappropriate use of endothelial cell lineages may lead to inaccurate responses.

\section{Ex vivo models to study angiogenesis}

\section{Rat aorta explant}

This assay was developed by Nicosia and Ottinetti (1990) and subsequently adapted for other species (Fig. 4). Isolated rat aorta is cut into segments yhat are placed in culture in biological matrices (collagen or fibrin) in the presence of the appropriate stimuli. Over the next 7-14 days, the explants are monitores for the outgrowth of endothelial and other cells. Quantification is achieved by measuring the number and lenght of microvessel outgrowth from the primary explants by visual counting or computer-assisted image analysis. Time-lapse videomicroscopy, immunohistochemical and ultrastructural studies can also be applied. A further modification of
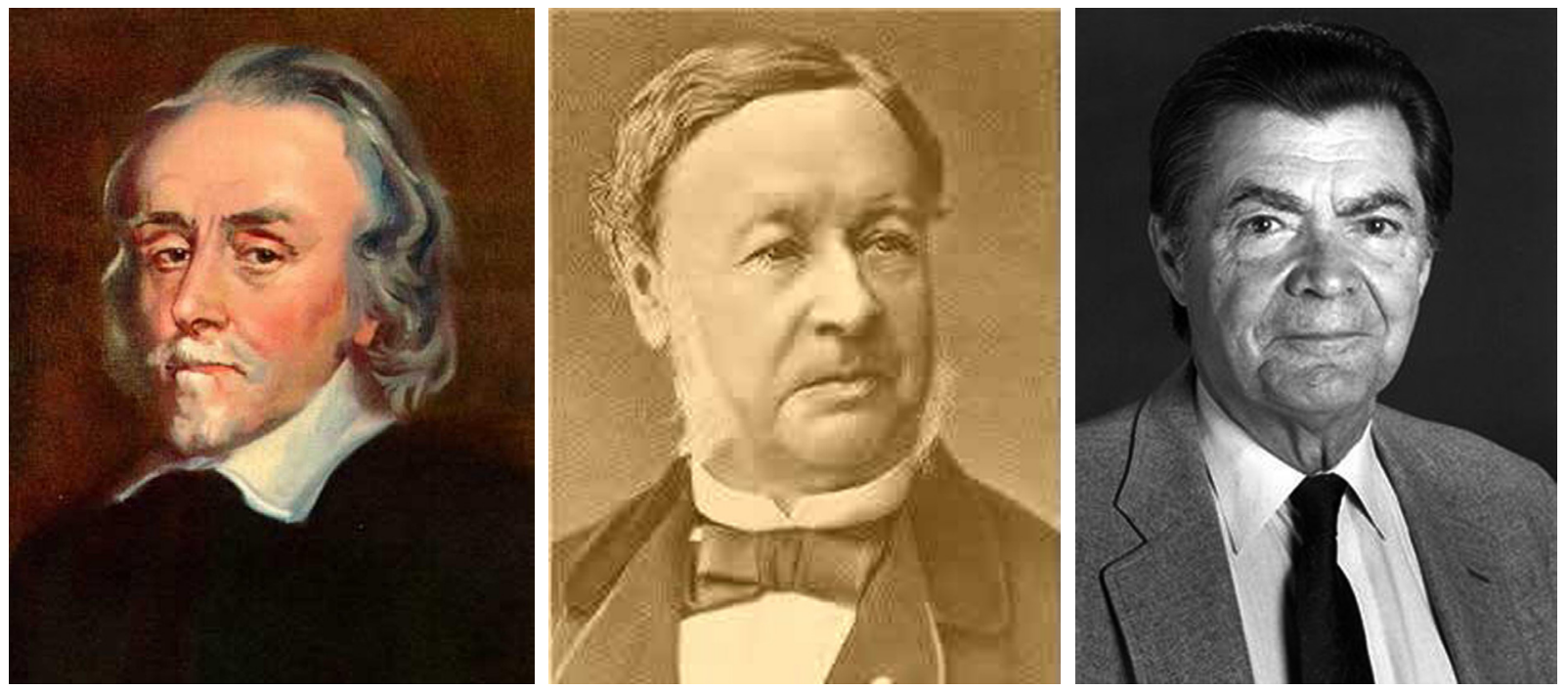

Fig. 1 (Left). William Harvey (1578 - 1657).

Fig. 2 (Center). Theodor Schwann (1810 - 1882).

Fig. 3 (Right). George E. Palade (1912 - 2008). Nobel Prize in Physiology and Medicine in 1974. 


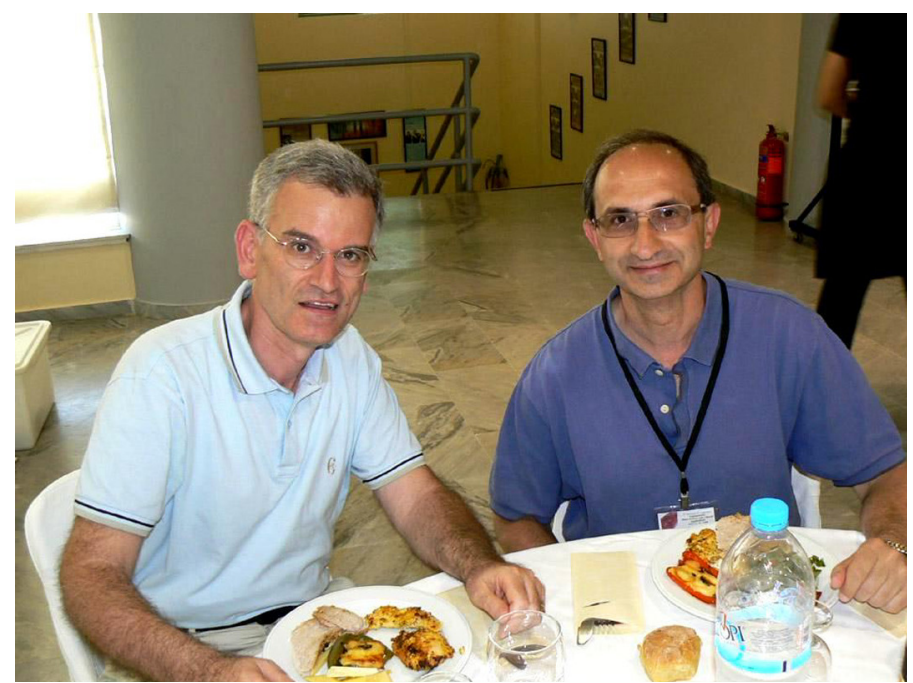

Fig. 4. Domenico Ribatti (left) with Roberto Nicosia (right). In occasion of the 9th international Conference on Angiogenesis (June 2008, Patras, Greece)

the rat aortic ring aortic ring assay is the chick aortic arch model.

\section{In vivo models to study angiogenesis}

\section{Rabbit ear chamber}

This is a chronic transparent tissue preparation that was developed by Sandison in 1924 and has been adapted for contnuous non-invasive monitoring of angiogenesis. In 1931, Clark and coworkers perfected the implantation of transpaent chambers in the rabbit's ear, allowing the study of the morphological characteristics of blood vessels in vivo.

\section{Dorsal skin and subcutaneous air sac}

The dorsal skin chamber was first introduced by Algire in 1943 and has been adapted for use in other rodents or placed in immunodeficient rodents. This assay permits continuous non invasive monitoring of vascular networks in vivo over 3-4 weeks.

The dorsal air sac model was developed by Selye in 1953 as a mean of monitoring the vascularization of tumor grafts. Cells or tissue fragments were introduced into an air pocket created on the dorsum of a rat temporarily creating a thin isolated vascularized membrane to establish a new blood supply. Angiogenesis was assessed using a dissecting microscope to count vessels or photographs of the skin for quantification of vessel density.

\section{Corneal micropocket assay}

The production of an angiogenic reaction in the cornea must be considered the most convincing demonstration of true vascularization, since the cornea is normally completely avascular. In 1973, Folkman and Gimbrone implanted tumor fragments with a size of no more than $0,5 \mathrm{~mm}^{3}$ into the rabbit cornea at a distance of $2 \mathrm{~mm}$ from the limbal edge. After 8-10 days new capillary blood vessels grew from the limbus, invaded the cornea and encircled the tumor implant in the absence of inflammation and vascularized tumor grew exponentially (Fig. 5) (Gimbrone, et al., 1973).

Substances used within the pocket have included tumor tissue, tumor cells, tumor extracts, other tissues and cells, conditioned medium, recombinant cytokines and/or growth factors incorporated into slow release pellets, such as Elvax of Hydron. The assay has been adapted for the use in the mouse eye (Muthukkaruppan and Auerbach, 1979) in order to take advantage of imbred strains, transgenic animals and the availability of a number of suitable reagents for these animals.

\section{Chick embryo chorioallantoic membrane assay}

The chick embryo chorioallantoic membrane (CAM) was described by experimental embryologists ore than 50 year ago and is probably the most widely used in vivo assay for studying angiogenesis (Ribatti, 2010). Folkman and associates introduced this assay in 1974 (Fig. 6) (Auerbach et al., 1974).

The CAM is a suitable site for transplanting tissues, which can survive and develop in the CAM by peripheral anastomoses between graft and original CAM vasculature or by new angiogenic vessels grown from the CAM that invade the graft. While the formation of peripheral anastomoses between host and pre-existing donor vessels is the main, and the most common, mechanism involved in the revascularization of embryonic grafts, the growth of CAMderived vessels into the graft is only stimulated in tumor grafts.

The CAM has long been a favored system for the study of tumor angiogenesis and metastasis, because a this stage the chick immunocompetence system is not fully developed and the conditions for rejection have not been established. Tumors remain avascular for $72 \mathrm{~h}$, after which they are penetrated by new blood vessels and begin a phase of rapid growth. The rate of growth during this vascular phase is greater for implants on days 5 and 6 , and decreases for later days of implantation. The CAM may also used to verify the ability to inhibit the growth of capillaries by

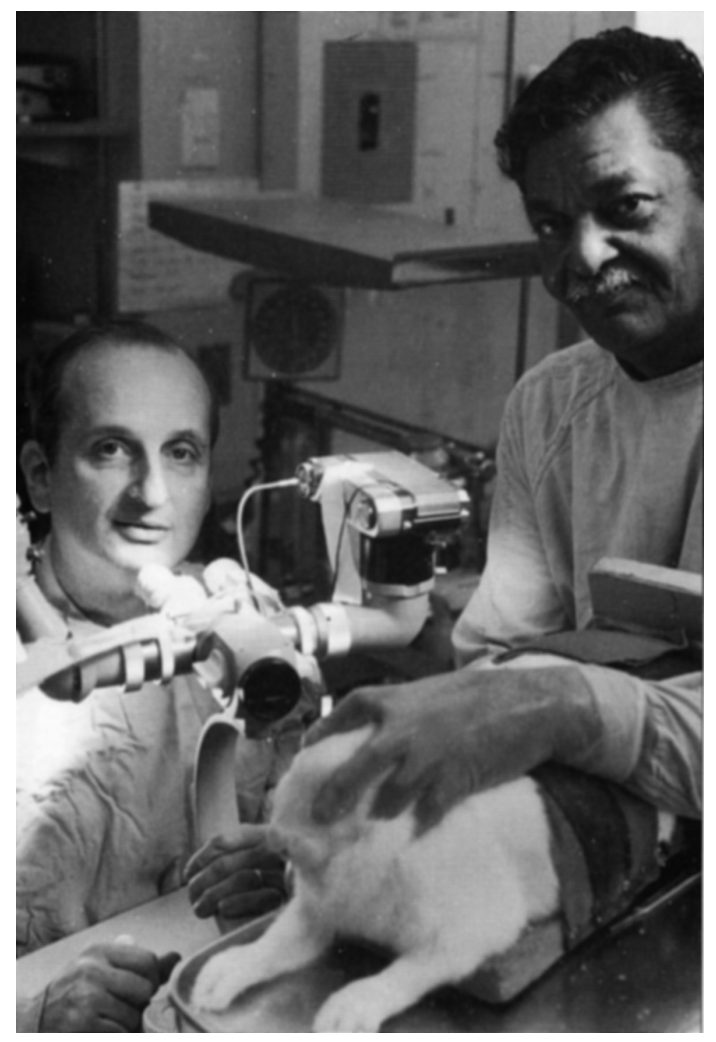

Fig. 5. Judah Folkman in collaboration with his technician photographing a rabbit eye. 1972, Folkman's Lab. 


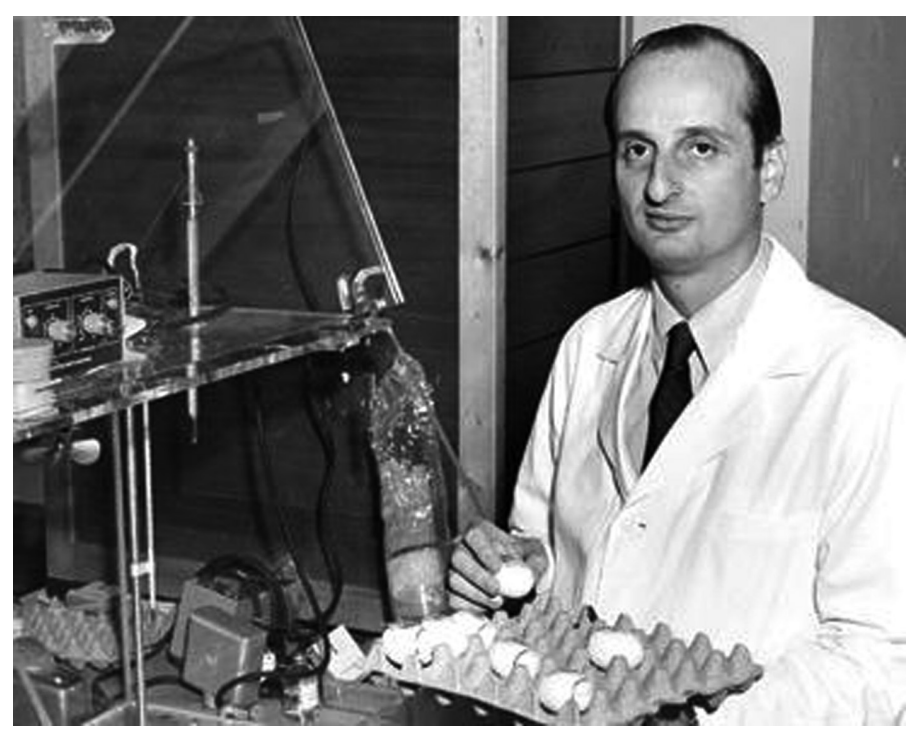

Fig. 6. Judah Folkman shows a lot of chick eggs used to perform the chorioallantoic membrane assay. 1974, Folkman's Lab.

implanting tumors onto the CAM and by comparing tumor growth and vascularization with or without the administration of an antiangiogenic molecule.

Other studies using the tumor cells/CAM model have focused on the invasion of the chorionic epithelium and the blood vessels by tumor cells. The cells invade the epithelium and the mesenchymal connective tissue below, where they are found in the form of a dense bed of blood vessels, which is a target for intravasation.

Also, delivery of tumor cells onto the CAM allows the fine study of the effects of tumor-derived angiogenic growth factors on blood vessel structure and functionality.

\section{The cannulated sponge model}

In 1987, Andrade and co-workers described a method of quantitating angiogenesis in sponge implants. After putting the agonist or antagonist of angiogenesis in circular polyether sponge discs with central cannulae, the subsequent change in blood flow can be measured by using the ${ }^{133} \mathrm{Xe}$ clearance technique for repeated measurement of relative blood flow changes through the sponges over a period of weeks. As the sponges originally contained no blood vessels, the increase in the rate of ${ }^{133} \mathrm{Xe}$ loss from the sponges was considered to represent neovascularization.

\section{The disc angiogenesis assay}

In 1988, Fajardo et al. described a new assay in which polyvinyl alcohol sponges are introduced subcutaneously in the host animal through a distal skin incision and then evaluated for penetration by host-derived blood vessels and/or other cell infiltrates. Angiogenic factors or antagonists are incorporated into a slow release polymer and placed in the centre of the sponge. The disc angiogenesis system has been modified to enable the introduction of live cells, i.e. tumor cells or inflammatory cells into the centre of the sponge.

Discs can be fixed, sectioned and stained. Histological examination of sections of the disc show a rich neovascularization and a distinctive cellular infiltration at the edges, including fibroblasts, endothelial cells and leukocytes.

\section{Morphogenesis on Matrigel}

Matrigel, a laminin-rich mixture of basement membrane components, was initially used to investigate capillary tube formation in vitro. Matrigel in liquid form at $4^{\circ} \mathrm{C}$ is mixed with an angiogenic cytokine and injected in the subcutaneous tissues of mice. At body temperature Matrigel rapidly forms a solid gel, trapping the growth factor to allow slow release and prolonged exposure to surrounding tissues. The animals are killed on day 10 and the Matrigel plugs excised for histologic examination. Angiogenesis is quantitated as vessel area in the plug section by image analysis. The quantitation of the angiogenic response may be also performed by hemoglobin content. This assay was originally described by Passaniti et al. in 1992, who injected Matrigel-containing FGF-2 subcutaneously into mice.

\section{Zebrafish}

The zebrafish (Dario rerio) has been recently introduced as an experimental model to study angiogenesis in vivo (Serbedzija et al., 1999; Chan et al., 2002). The development of blood vessels, such as the dorsal aorta, posterior cardinal vein, subintestinal veins and intersegmental vessels in early zebrafish embryos is well characterized through analysis of mutations affecting their formation and as the embryos develop outside the mother and are transparent, the direct observation of blood vessel formation is straight forward using just a low-power microscope. Moreover, it is possible to undertake specific gene knockdown by antisense morpholino oligonucleotides, which allow rapid assessment of gene function in angiogenesis.

More recently, Nicoli and Presta (2007) have proposed to use this assay to inject peptides, proteins or tumor cells suspensions in the yolk sac of embryos to evaluate their angiogenic capability (Fig. 7).

\section{Tumor models}

Different in vivotumor models have been developed to study the activity of anti-cancer treatments. Tumors can be grown syngeneiclly (subcutaneous), orthotopically (in the organ site of origin), or as xenografts in immunodeficient recipient. A major disadvantage of

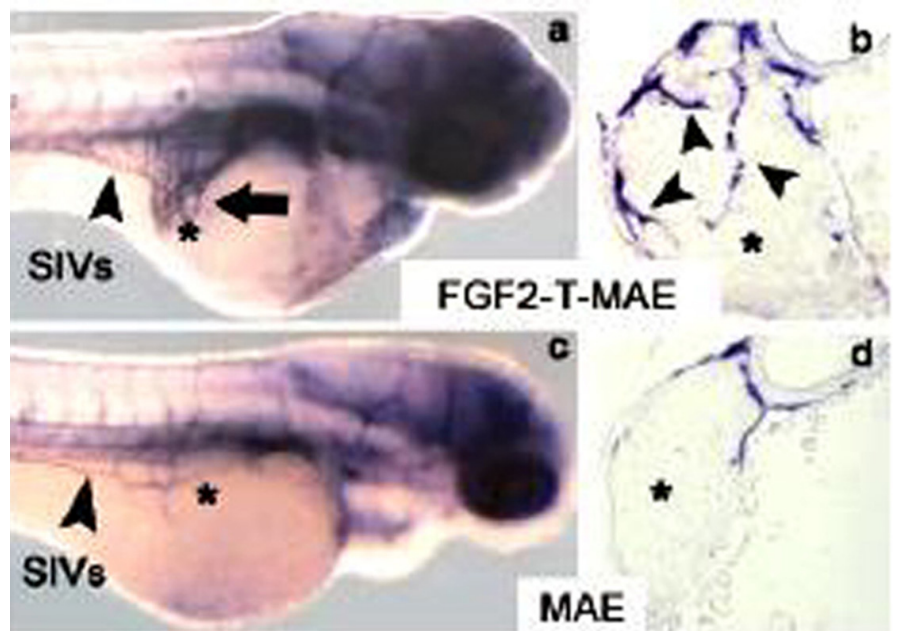

Fig. 7. Angiogenic response triggered by mouse aortic endothelial cells transfected with FGF2 (FGF2-T-MAE) implanted in the SIV space of zebrafish embryo, as compared with non transfected cells (MAE). (courtesy of Prof. Marco Presta). 
all the tumor models is that tumors are established within a few weeks after cell implantaion, whereas human cancer develops over a period o several months or years. Tumor models can be also used to investigate antiangiogenic drugs.

\section{Concluding remarks}

The assays to study angiogenesis in vitro and in vivo have enabled to make up important progress in elucidating the mechanism of action of several angiogenic factors and inhibitors. A variety of animal models have ben described to provide more quantitative analysis of in vivo angiogenesis and to characterize pro- and antiangiogenic molecules.

The ideal assay would be reliable, technically straighforward, easily quantifiable and physiologically relevant. None of the presently used assay systems allows an objective evaluation of the various components of the process of angiogenesis and a 'gold standard'angiogenesis assay has yet to be developed. Ideally, almost two different assays should be performed in parallel to confirm the angiogenic or antiangiogenic activities of test substances.

\section{Acknowledgements}

This work was supported by grant PN /I 41-054/2007 of Romanian Ministry of Research and Education, by MIUR (PRIN 2007), Rome, and Fondazione Cassa di Risparmio di Puglia, Bari, Italy.

\section{References}

ALGIRE, G.H. (1943). Microscopic studies of the early growth of a transplantable melanoma of the mouse using the transparent chamber technique. J Natl Cancer Inst 4: 1.

AL-GHAZAL, S.K. (2007). Ibn al-Nafis and the Discovery of Pulmonary Circulation. Manchester: FSTC 684: 1-7.

ALLT, G. and LAWRENSON, J.G. (2001) Pericytes: Cell Biology and Pathology. Cells Tissues Organs 169:1-11

ANDRADE, S.P., FAN, T.P.D. and LEWIS, G.P. (1987). Quantitative in vivo studies on angiogenesis in a rat sponge model. Brit J Exp Pathol 68: 755-766.

AUERBACH, R., KUBAI, L., KNIGHTON, D.R. and FOLKMAN, J. (1974). A simple procedure for the long-term cultivation of chicken embryos. Dev Biol 41: 391-394.

BROWN, K.J., MAYNES, S.F., BEZOS, A., MAGUIRE, D.J., FORD, M.D. and PARISH, C.R. (1996) A novel in vitro assay for human angiogenesis. Lab Invest 75:539-555.

CHAN, J., BAYLISS. P.E., WOOD, J.M. and ROBERTS, T.M. (2002). Dissection of angiogenic signaling in zebrafish using a chemical genetic approach. Cancer Cell 1: 257-267.

CLARK, E.R., HITSCHLER, W.J., KIRBY-SMITH, H.T., REX, R.O. and SMITH, J.H. (1931). General observations on the ingrowth of new blood vessels into standardized chambers in the rabbit's ear, and the subsequent changes in the newly grown vessels over a period of months. Anat Rec 50:129-167.

CLARK, E.R. (1936). Growth and development of function in blood vessels and lymphatics. Annals Int. Med. 9:1043-1049.

CLARK, E.R. and CLARK, E.I. (1939). Microscopic observations on the growth of blood capillaries in the living mammals. Am J Anat 64:251-301.

CRIVELLATO, E. and RIBATTI, D. (2006) Aristotle: the first student of angiogenesis. Leukemia 20:1209-1210.

FAJARDO, L.F., KOWALSKI, J., KWAN, H.H., PRIONAS, S.D. and ALLISON, A.C. (1988). The disc angiogenesis system. Lab Invest 158: 718-724.

FANCHER, T.T., MUTO, A., FITZGERALD, T.N., MAGRI, D., GORTLER, D., NISHIBE, T. and DARDIK, A. (2008) Control of Blood Vessel Identity: From Embryo to Adult. Ann Vasc Dis 1: 28-34

FIGG, D.V. and FOLKMAN, J. (2008). Angiogenesis: An Integrative Approach from Science to Medicine. Springer Verlag

FLAMME, I., and RISAU, W. (1992). Induction of vasculogenesis and hematopoiesis in vitro. Development 116: 435-439.

FOLKMAN, J. and HAUDENSCHILD, C. (1980) Angiogenesis in vitro. Nature 288:551-556.

FOLKMAN, J., HAUDENSCHILD, C. C. and ZETTER, B. R. (1979). Long-term culture of capillary endothelial cells. Proc. Nat. Acad. Sci. USA 76: 5217-5221.

GIMBRONE, M.A. Jr., LEAPMAN, S.B., COTRAN, R.S. and FOLKMAN, J. (1973) Tumor angiogenesis: iris neovascularization at a distance from experimental intraocular tumors. J Natl Cancer Inst 50:219-228.

GOLDMAN E. (1907)The growth of malignant disease in man and the lower animals with special reference to the vascular system. Lancet 2:1236-1240.

HAUDENSCHILD, C.C., COTRAN, R.S., GIMBRONE, M.A. Jr. and FOLKMAN J. (1975) Fine structure of vascular endothelium in culture. Ultrastruct Res.50:22-32.

HIS, W. (1865). Die Häute und Höhlen des Körpers. Basel.

HOFFMAN, R.M. (1999,a). Green fluorescent protein to visualize cancer progression and metastasis. Methods in Enzymology, Green Fluorescent Protein, Vol. 302 Ed: P. Michael Conn, Academic Press, San Diego, pp. 20-31.

HWA, C. and AIRD, W.C. (2007). The history of the capillary wall: doctors, discoveries, and debates. Am J Physiol Heart Circ Physiol 293:H2667-79.

IDE, A.G., BAKER, N.H. and WARREN BA.(1939).Vascularization of the BrownPearce rabbit epithelioma transplant as seen in the transparent ear chamber. Am J Roentgenol 32:891-899.

INGBER, D.E., MADRI, J.A. and FOLKMAN, J. (1987). Endothelial growth factors and extracellular matrix regulate DNA synthesis through modulation of cell and nuclear expansion. In vitro Cell Dev Bio. 23:387-394.

JAFFE, E.A., NACHMAN, R.L., BECKER. C.G. and MINICK, C.R. (1973). Culture of Human Endothelial Cells Derived from Umbilical Veins. Identification by morphologic and immunologic criteria. J Clin Invest 52: 2745-2756.

KATZ,A.M.(1957). Knowledge of the circulation before William Harvey. Circulation 15:726-734.

KHAN, I.A., DAYA, S.K., and GOWDA, R.M. (2005). Evolution of the theory of circulation. Int J Cardiol 98: 519-521.

LEWIS, W.H. (1936): Malignant cells. In: "The Harvey Lectures," Vol. 31. Baltimore: Williams \& Wilkins, pp. 214-234.

LOUKAS, M., CLARKE, P., TUBBS, R.S., KAPOS, T., and TROTZ, M (2008). The His family and their contributions to cardiology. Int J Cardiol 123:75-78

MOVAT, H.G., FERNANDO, N.V.P(1964). The fine structure of the terminal vascular bed: IV. The venules and their perivascular cells (perycites, adventicial cells). Exp. Molec. Pathol. 3: 98-114.

MURPHY, J.B. (1926). Observations on the etiology of tumors: as evidences by experiments with a chicken sarcoma. JAMA 86:1270-1271.

MUTHUKKARUPPAN, V. and AUERBACH, R. (1979) Angiogenesis in the mouse cornea. Science 206: 1416-1418.

NICOLI, S. and PRESTA, M. (2008). The zebrafish/tumor xenograft angiogenesis assay. Nat Protoc 2:2918-2923.

NICOSIA, R.F. and OTTINETTI, A.(1990) Growth of microvessels in serum-free matrix culture of rat aorta. A quantitative assay of angiogenesis in vitro. Lab Invest 63:115-122.

PASSANITI, A., TAYLOR, R.M., PILI, R. et al. (1992). A simple, quantitative method for expressing angiogenesis and antiangiogenic agents using reconstituted basement membrane, heparin, and fibroblast growth factor. Lab Invest 67: 519-528.

PAWELETZ, N. (2001). Birth of the life sciences in The Netherlands and Belgium. Nat. Rev. Mol. Cell. Biol 2: 857.

PRIORESCHI, P. (2004). Andrea Cesalpino and systemic circulation. Ann Pharm Fr.62:382-400

RIBATTI D (2009). William Harvey and the discovery of the circulation of the blood. $J$ Angiogenesis Res 1: 3.

RIBATTI D (2010). The contribution of Roberto Montesano to the study of interactions between epithelial sheets and the surrounding extracellular matrix. Int $J$ Dev Biol 54:1-6

RIBATTI, D. (2010). The chick embryo chorioallantoic membrane in the study of angiogenesis and metastasis. Springer Science, Dordrecht, Heidelberg, London, New York.

SANDERS, A.G., EBERT, R.H. and FLOREY, H.W.(1940). The mechanism of capillary contraction. Exp. Physiol. 30: 281-287 
382 A.M. Cimpean et al.

SANDISON, J. C (1924). A new method for the microscopic study of living growing tissues by the introduction of a transparent chamber in the rabbit's ear. Anat Rec 28: 281-287.

SCHWANN, T. and SCHLEIDEN, M.J. (Ed.) (1847). Microscopical researches into the accordance in the structure and growth of animal and plants. The Sydenham Society, London.

SELYE, H. (1953). On the mechanism through which hydrocortisone affects resistance of tissues to injury. J Am Med Assoc 152: 1207-1213

SERBEDZIJA, G.N., FLYNN, E. and WILLETT, C.E. (1999). Zebrafisg angiogenesis: a new model for drug screening. Angiogenesis 3: 353-359.

SPALTEHOLZ, W. and HIRSCH, C. (1907) Coronararterien und Herzmuskel: Anato- mische und experimentelle Untersuchungen. Dtsch. Med. Wochenschr. 1: 790.

WARKANY, J. (1981) Friedrich Daniel von Recklinghausen and his times. Adv Neurol 29:251-257.

WEIBEL, E.R. and PALADE, G.E. (1964). New cytoplasmic components in arterial endothelia J. Cell Biol 23: 101-112

WILLERSON, J.T. and TEAFF, R. (1996) Egyptian contributions to cardiovascular medicine. Texas Heart Inst. J. 3: 191-200

WOODWARD, J.J. (1870).Report on certain points connected with the histology of minute blood-vessels. Q J Microsc Sci 10: 380-393.

ZWEIFACH, B.W. and KOSSMAN, C.E. (1937). Micromanipulation of small blood vessels in the mouse. Am J Physiol 120: 23-35. 


\section{Further Related Reading, published previously in the Int. J. Dev. Biol.}

See our recent Special Issue Placenta edited by Joan S. Hunt and Kent L. Thornburg at: http://www.ijdb.ehu.es/web/contents.php?vol=54\&issue=2-3

The seminal work of Werner Risau in the study of the development of the vascular system Domenico Ribatti

Int. J. Dev. Biol. (2010) 54: 567-572

The contribution of Roberto Montesano to the study of interactions between epithelial sheets and the surrounding extracellular matrix Domenico Ribatti

Int. J. Dev. Biol. (2010) 54: 1-6

Parallels in invasion and angiogenesis provide pivotal points for therapeutic intervention Suzanne A. Eccles

Int. J. Dev. Biol. (2004) 48: 583-598

Angiogenesis and apoptosis are cellular parameters of neoplastic progression in transgenic mouse models of tumorigenesis G Bergers, D Hanahan and L M Coussens

Int. J. Dev. Biol. (1998) 42: 995-1002

The chick embryo chorioallantoic membrane as a model for in vivo research on angiogenesis D Ribatti, A Vacca, L Roncali and F Dammacco Int. J. Dev. Biol. (1996) 40: 1189-1197

$$
5 \text { yr ISI Impact Factor }(2009)=3.253
$$

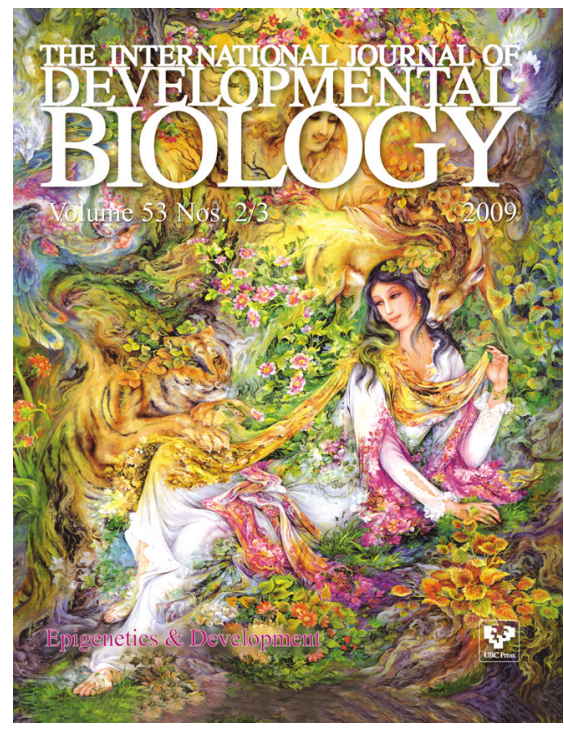

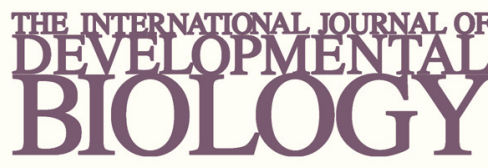

Volume 54 Nos. 6/7

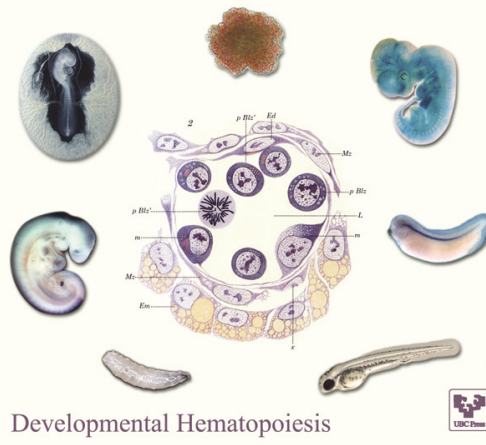

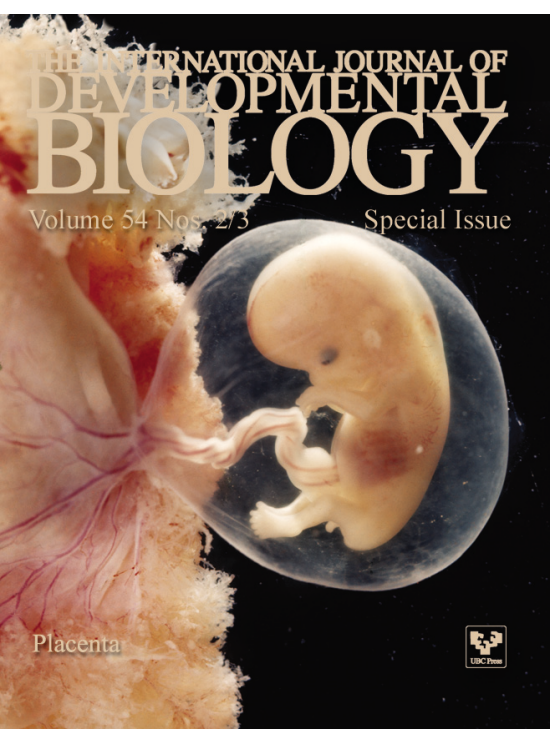

